http://dx.doi.org/10.11646/zootaxa.3835.1.3

http://zoobank.org/urn:lsid:zoobank.org:pub:A3E750E2-F138-4369-A610-1F7E2CB71164

\title{
Description of the tadpoles of three rare species of megophryid frogs (Amphibia: Anura: Megophryidae) from Gunung Mulu, Sarawak, Malaysia
}

\author{
EVELYNE OBERHUMMER ${ }^{1,2}$, CATHERIN BARTEN ${ }^{1,2}$, MANUEL SCHWEIZER $^{2}$, \\ INDRANEIL DAS ${ }^{3}$, ALEXANDER HAAS $^{4} \&$ STEFAN T. HERTWIG ${ }^{2}$ \\ ${ }^{1}$ University of Bern, Institute of Ecology and Evolution, Baltzerstrasse 6, CH-3012 Bern. \\ E-mail: catherin.barten@students.unibe.ch,evelyne.o@gmx.ch \\ ${ }^{2}$ Naturhistorisches Museum der Burgergemeinde Bern, Bernastrasse 15, CH-3005 Bern, Switzerland. \\ E-mail: stefan.hertwig@nmbe.ch, manuel.schweizer@nmbe.ch \\ ${ }^{3}$ Institute of Biodiversity and Environmental Conservation, University Malaysia Sarawak, 94300 Kota Samarahan, Sarawak, Malay- \\ sia.E-mail:idas@ibec.unimas.my \\ ${ }^{4}$ Biozentrum Grindel und Zoologisches Museum Hamburg, Martin-Luther-King-Platz 3, 20146 Hamburg, Germany. \\ E-mail: alexander.haas@uni-hamburg.de
}

\begin{abstract}
The megophryid frogs Leptobrachella brevicrus, Leptolalax dringi and Megophrys dringi are species exclusively known from highly localised areas in isolated mountain ranges on Borneo. The tadpoles and adults in this study were collected at the shared type locality for the three species in Gunung Mulu National Park, Sarawak, Malaysia (Borneo). The species identities of larvae were determined via comparison to syntopic adults using DNA barcoding techniques based on partial 16S rRNA mitochondrial gene sequences. The genetic data supported the status of the three taxa as valid species. Descriptions of colouration in life and after preservation, external morphological features, morphometric measurements and ecological notes in comparison to congeneric species are supplied. The tadpoles of L. brevicrus and L. dringi show similar adaptations to a fossorial lifestyle. These include an elongated, vermiform body, a relatively long tail and small eyes. Both were found in the gravel beds of a small mountain stream. In contrast, the larvae of $M$. dringi are adapted to occupying and feeding at the surface of pools within the stream.
\end{abstract}

Key words: Borneo, Leptobrachella brevicrus, Leptolalax dringi, Megophrys dringi, anuran larvae, external morphology, fossorial tadpole, rheophilic tadpole, phylogenetic relationships, DNA barcoding

\section{Introduction}

Although the true number of amphibian species on Borneo is probably vastly underestimated (Inger 1999; Inger et al. 2006), the island is already considered a biodiversity hotspot for amphibians of global importance (Myers et al. 2000). Its fauna is known to include a large number of micro-endemic species, many of them from the numerous isolated peaks and ridges of the mountain range in the north-eastern part of Borneo (e.g. Inger 1966; Dring 1983; 1983, 1987; Inger \& Stuebing 1997, 2005; Dehling 2008, 2010, 2011). Gunung Mulu National Park in north-eastern Sarawak, Malaysia (Borneo) protects the sandstone formation of the Gunung Mulu massif, which rises up to reach 2,376 $\mathrm{m}$ a. s. 1., and the limestone mountains of the Melinau formation (Hazebroek \& Morshidi 2000).

The various species of Megophryidae Bonaparte are distributed across South and South-East Asia (amphibiaweb.org 2013; Frost 2014; Lathrop 1997; Li et al. 2011), making a significant contribution to the extraordinarily high amphibian diversity found on the islands of Sundaland. Borneo, the largest land unit of Sundaland, is home to 26 reported species of megophryid frogs, several of which have been discovered and described only recently (Inger \& Stuebing 1997, 2005; Hamidy et al. 2012). Most megophryid frogs are nocturnal inhabitants of the floor of subtropical or tropical forests and are characterised by their impressive camouflage 